\title{
DENGUE HEMORRHAGIC FEVER : SEBUAH LAPORAN KASUS
}

\author{
${ }^{1)}$ Amrizal Amir, ${ }^{2}$ Fitrach Desfiyanda, ${ }^{3)}$ Ria Finola Ifani \\ ${ }^{1,2)}$ Bagian Ilmu Penyakit Dalam, RSUD Kota Dumai \\ ${ }^{1,2)}$ Jl. Tanjung Jati No.4, Dumai Timur, Kota Dumai, Riau, 28812 \\ ${ }^{3)}$ Fakultas Kedokteran, Universitas Abdurrab \\ 3) Jl. Riau Ujung No. 73 Pekanbaru - Riau - Indonesia \\ E-mail : ${ }^{1)}$ amrizal.amir@univrab.ac.id,${ }^{3)}$ ria.finola.i16@ student.univrab.ac.id
}

\section{Kata Kunci:}

Dengue hemorrhagic fever grade II, DBD, trombositopenia, hematocrit, ringer laktat
Keywords:

Dengue hemorrhagic fever grade II, DHF, thrombocytopenia, hematocrit, Ringer's lactate

\section{Info Artikel}

Tanggal dikirim: 15-1-2021

Tanggal direvisi: 22-1-2021

Tanggal diterima: 29-1-2021 DOI Artikel:

10.36341/cmj.v4i1.2162

Attribution-NonCommercial 4.0 International. Some rights reserved

\begin{abstract}
ABSTRAK
Telah dilakukan tindakan pada seorang pasien laki-laki berusia 18 tahun yang dibawa ke IGD RSUD Dumai dengan keluhan demam sejak 5 hari yang lalu. Demam dirasakan terus menerus. Demam disertai menggigil dan berkeringat dingin.Pasien mengeluhkan sakit kepala dibagian frontal sejak 4 hari yang lalu. Pasienmengeluhkan nyeri perut sejak 4 hari yang lalu di seluruh perut. BAB dan BAK lancar. Sejak demam nafsu makan menurun tetapi minum cukup. Pasien mengeluhkan nyeri perut sejak 4 hari yang lalu di seluruh perut. BAB dan BAK normal. Sejak demam nafsu makan menurun tetapi minum cukup. Pasien merasakan mual dan muntah. Pasien mimisan 4 hari yang lalu. Dari beberapa jenis pemeriksaan yang telah dilakukan maka diagnose pasien adalah Dengue hemorrhagic fever grade II. Dalam mendiagnosis DHF berdasarkan kriteria WHO diagnosis DBD ditegakkan bila demam $+\geq 2$ menifestasi klinis + trombositopenia dan hemokonsentrasi/peningkatan hematokrit. Pada pasien ini terdapat demam dan 2 manifestasi klinis yaitu demam bifasik + epistaksis. Dalam mendiagnosis DHF berdasarkan hal tersebut, kemungkinan diagnosis untuk pasien ini adalah DHF grade 2 karena pada pemeriksaan penunjang terdapat trombositopenia dan adanya hemokonsentrasi. Penatalaksanaan pada pasien ini termasuk Grup B yaitu terapi cairan ringer laktat 47 tetes/menit makro, kemudian injeksi ranitidine, paracetamol sebagai antipiretik dan juga dehaf sebagai suplemen.
\end{abstract}

\begin{abstract}
An action has been taken on an 18 year old male patient who was brought to the ER at the Dumai General Hospital with complaints of fever since 5 days ago. Fever is felt continuously. Fever accompanied by chills and cold sweats. The patient complained of headache in the frontal area since 4 days ago. The patient complained of abdominal pain since 4 days ago all over the abdomen. CHAPTER and BAK smoothly. Since fever decreased appetite but drink enough. The patient complained of abdominal pain since 4 days ago all over the abdomen. normal bowel and bladder. Since fever decreased appetite but drink enough. The patient feels nausea and vomiting. The patient had a nosebleed 4 days ago. From several types of examinations that have been carried out, the patient's diagnosis is Dengue hemorrhagic fever grade II. In diagnosing DHF based on WHO criteria, the diagnosis of DHF is established when fever +2 manifests clinically + thrombocytopenia and hemoconcentration/increased hematocrit. This patient had fever and 2 clinical manifestations, namely biphasic fever + epistaxis. In diagnosing DHF based on this, the possible diagnosis for this patient is DHF grade 2 because on investigation there is thrombocytopenia and hemoconcentration. The management of this patient included Group B, namely Ringer's lactate fluid therapy 47 drops/minute macro, then ranitidine injection, paracetamol as an antipyretic and also dehah as a supplement.
\end{abstract}

\section{PENDAHULUAN}

Demam dengue (DF) dan demam berdarah dengue (DHF) adalah penyakit infeksi yang disebabkan oleh virus dengue dengan manifestasi klinis demam, nyeri otot atau nyeri sendi yang disertai leukopenia, ruam, limfadenopati, dan trombositopenia dan diatesis hemoragik. Pada DBD terjadi perembesan plasma yang ditandai dengan hemokonsentrasi (peningkatan hematokrit) atau penumpukan cairan di rongga tubuh. Sindrom Renjatan Dengue ( Dengue Syok Syndrome) adalah demamberdarah dengue yang ditandai oleh 
syok [1].

Demam dengue merupakan wabah infeksi virus paling cepat menyebar yang disebarkan oleh nyamuk Aedes dan menjadi perhatian dalam departemen kesehatan masyarakat pada lebih dari 100 negara tropis dan subtropis di Timur Laut Asia, Pasifik Barat dan Selatan, serta Amerika Tengah [2]. Demam dengue pertama kali muncul di Pakistan pada tahun 1994-1995 di Karachi.

Penularan infeksi virus Dengue terjadi melalui vector nyamuk genus Aedes (terutama A. aegypti dan A. albopticus). Peningkatan kasus setiap tahunnya berkaitan dengan sanitasi lingkungan dengan tersedianya tempat perindukan bagi nyamuk betina yaitu bejana yang berisi air jernih(bak mandi, kaleng bekas dan tempat penampungan air lainnya) [1]. Masa inkubasi virus dengue dalam manusia berkisar antara 3-14 hari sebelum gejala muncul. Gejala klinis rata-rata muncul pada hari ke 4- 7, sedangkan masa inkubasi ekstrinsik (di dalam tubuh nyamuk) berlangsung sekitar 8-10 hari [3].

\section{LAPORAN KASUS}

Seorang pasien laki-laki berusia 18 tahun dibawa ke IGD RSUD Dumai dengan keluhan demam sejak 5 hari yang lalu. Demam dirasakan terus menerus. Demam disertai menggigil dan berkeringat dingin.Pasien mengeluhkan sakit kepala dibagian frontal sejak 4 hari yang lalu. Pasien mengeluhkan nyeri perut sejak 4 hari yang lalu di seluruh perut. BAB dan BAK lancar. Sejak demam nafsu makan menurun tetapi minum cukup. Pasien merasakan mual (+), muntah (+) sejak 3 hari yang lalu. Muntah bercampur air dan darah. Gusi berdarah (-) Mimisan 4 hari yang lalu. Nyeri tenggorokan (-) Nyeri dibelakang mata (-) Sesak (-)

\section{Pemeriksaan Tanda Vital}

- Keadaan Umum : Tampak sakit ringan

- Kesadaran : Komposmentis

- Tinggi Badan : $168 \mathrm{~cm}$

- Berat Badan : $53 \mathrm{~kg}$
- Status Gizi : Normal

- Tekanan darah: $110 / 80 \mathrm{mmHg}$

- Denyut Nadi : $80 \times /$ menit

- Suhu tubuh $: 36,5^{\circ} \mathrm{C}$

- Frekuensi nafas : $18 \times /$ menit

Pemeriksaan Fisik Diagnostik

$\underline{\text { Skema Manusia }}$

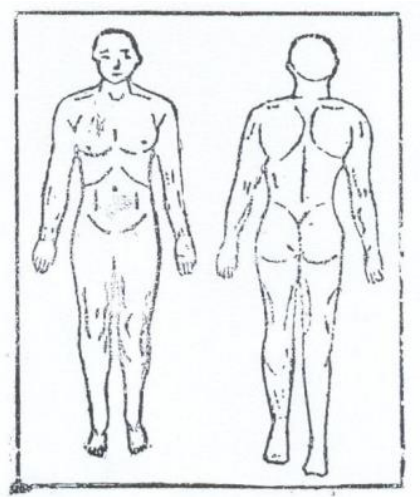

Gambarkan pada skema diatas jika ada kelainan lokal dan berikan keterangan secukupnya.

- Status Lokalis:

\section{Pemeriksaan Kepala}

Ukuran dan bentuk

Hidrosefalus/ Mikrosefalus

Simetrisitas Wajah

Simetris/Asimetris

Rambut

: Hitam

\section{Pemeriksaan Mata}

Kelopak /Palpebra : Normal/

hordeolum(-), calazion(-)

Konjungtiva

edem (-),

/-)

Sklera : ikterik (-

/-)

Kornea

: jernih

Pupil

: isokor

\section{Pemeriksaan Leher}

Inspeksi

simetris, tidak ada tanda-tanda

radang

Palpasi : tidak ada

pembesaran KGB

Pemeriksaan Trakea : deviasi (-

)

Pemeriksaan Kelenjar Tiroid : tidak

ada

: tidak ada

pembesaran 


\section{Pemeriksaan JVP $\quad: 5 \pm 2$ $\mathrm{cmH}_{2} \mathrm{O}$}

\section{Pemeriksaan Thorak}

Paru

Inspeksi : normochest, retraksi (-)

Palpasi : fremitus taktil simetris

\begin{tabular}{|c|c|}
\hline $\begin{array}{l}\text { Perkusi } \\
\text { paru }\end{array}$ & : Sonor pada kedua lapang \\
\hline $\begin{array}{l}\text { Auskultasi } \\
\text { wheezing (-/ } \\
\text { Jantung }\end{array}$ & $\begin{array}{l}\text { : Vesikular, rhonki (-/-), } \\
-) \text {, }\end{array}$ \\
\hline Inspeksi & : iktus kordis tidak terlihat \\
\hline $\begin{array}{l}\text { Auskultasi } \\
5 \text { kali/menit }\end{array}$ & : bising usus \\
\hline $\begin{array}{l}\text { Perkusi } \\
\text { seluruh lapang }\end{array}$ & perut \\
\hline $\begin{array}{l}\text { Palpasi } \\
(-) \text {, nyeri lep }\end{array}$ & ri tekan \\
\hline $\begin{array}{l}\text { Pemeriksaan } ₹ \\
\text { Pemeriksaan I }\end{array}$ & $\begin{array}{l}\text { : tidak teraba } \\
\text { syeri CVA: tidak ada nyeri }\end{array}$ \\
\hline
\end{tabular}

Pemeriksaan hepar : tidak ada

pembesaran

Pemeriksaan lien : tidak ada

pembesaran

Pemeriksaan asites : shifting

dullness (-)

Pemeriksaan Ekstrimitas

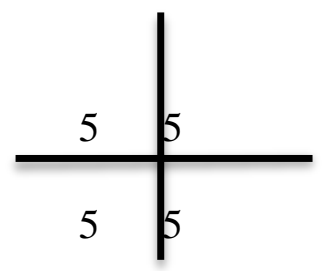

\section{O CRT \\ ○ Akral}

\section{Diagnosis dan Diagnosis Banding}

Diagnosis : Dengue hemorrhagic fever grade II

Diagnosis banding : cikungunya, malaria

\section{METODE TINDAKAN}

1. Tindakan Diagnostik/ Pemeriksaan Penunjang Pemeriksaan Penunjang Darah rutin

$\begin{array}{ll}\text { Hemoglobin (hb) } & : 12,8 \mathrm{gr} / \mathrm{dL} \\ \text { Jumlah leukosit } & : 12.800 \mathrm{~mm}^{3} \\ \text { Jumlah trombosit } & : 86.000 \mathrm{~mm}^{3} \\ \text { Eosinofil } & : 1 \% \\ \text { Netrofil batang } & : 0 \% \\ \text { Neutrofil segmen } & : 82 \% \\ \text { Limfosit } & : 9 \% \\ \text { Monosit } & : 7 \% \\ \text { Jumlah eritrosit } & : 4.470 .000 \mathrm{~mm}^{3} \\ \text { MCV } & : 84 \mathrm{FL} \\ \text { MCH } & : 28 \mathrm{PG} \\ \text { MCHC } & : 34 \% \\ \text { Hematokrit } & : 38 \% \\ \text { 2. Tindakan Terapi } & \\ \text { Farmakologi } & \\ \text { IVFD RL 30 TPM } & \\ \text { INJ. Ranitidine 1 AMP } \\ \text { INJ Ondansentron 1 AMP } \\ \text { Paracetamol 3x1 }\end{array}$

\section{Prognosis}

Ad Vitam

Ad Fungsionam

Ad Sanationam : Bonam

: Bonar

: Bonar

\section{PEMBAHASAN}

Tn.A 18 tahun didiagnosis sebagai Dengue hemorragic fever didasarkan pada anamnesis, pemeriksaan fisik dan pemeriksaan penunjang. Dari anamnesis didapatkan pasien mengeluhkan demam sejak 5 hari yang lalu. Demam dirasakan terus menerus. Demam disertai menggigil dan berkeringat dingin. Pasien mengeluhkan sakit kepala dibagian frontal sejak 25 thari yang lalu disertai badan lemas.

Pssien mengeluhkan nyeri perut sejak 4 hari yang lalu di seluruh perut. BAB dan BAK normal. Sejak demam nafsu makan menurun tetapi minum cukup. Pasien merasakan mual (+) muntah (+). Pasien mimisan 4 hari yang lalu.

Dalam mendiagnosis DHF berdasarkan kriteria WHO diagnosis DBD ditegakkan bila demam $+\geq 2$ menifestasi klinis + trombositopenia dan hemokonsentrasi/peningkatan hematokrit. Pada pasien ini terdapat demam dan 2 manifestasi klinis yaitu demam bifasik + 
epistaksis. Dalam mendiagnosis DHF berdasarkan hal tersebut, kemungkinan diagnosis untuk pasien ini adalah DHF grade 2 karena pada pemeriksaan penunjang terdapat trombositopenia dan adanya hemokonsentrasi.

Penularan virus dengue terjadi melalui gigitan nyamuk yang termasuk subgenus Stegomya yaitu nyamuk Aedes aegypti dan Ae. albopictus sebagai vektor primer dan Ae. polynesiensis, Ae.scutellaris serta Ae (Finlaya) niveus sebagai vektor sekunder [4], selain itu juga terjadi penularan transexsual dari nyamuk jantan ke nyamuk betina melalui perkawinan [4] serta penularan transovarial dari induk nyamuk ke keturunannya [5]. Ada juga penularan virus dengue melalui transfusi darah seperti terjadi di Singapura pada tahun 2007 yang berasal dari penderita asimptomatik [6]. Dari beberapa cara penularan virus dengue, yang paling tinggi adalah penularan melalui gigitan nyamuk Ae. Aegypti [7].

Salah satu faktor risiko penularan DBD adalah pertumbuhan penduduk perkotaan yang cepat, mobilisasi penduduk karena membaiknya sarana dan prasarana transportasi dan terganggu atau melemahnya pengendalian populasi sehingga memungkin terjadinya KLB. Faktor risiko lainnya adalah kemiskinan yang mengakibatkan orang tidak mempunyai kemampuan untuk menyediakan rumah yang layak dan sehat, pasokan air minum dan pembuangan sampah yang benar. Tetapi di lain pihak, DBD juga bisa menyerang penduduk yang lebih makmur terutama yang biasa bepergian. Dari penelitian di Pekanbaru Provinsi Riau, diketahui faktor yang berpengaruh terhadap kejadian DBD adalah pendidikan dan pekerjaan masyarakat, jarak antar rumah, keberadaan tempat penampungan air, keberadaan tanaman hias dan pekarangan serta mobilisai penduduk; sedangkan tata letak rumah dan keberadaan jentik menjadi faktor risiko.

Penatalaksanaan pada pasien dalam kasus ini termasuk Grup B yaitu terapi cairan ringer laktat 47 tetes/menit makro, kemudian injeksi ranitidine, paracetamol sebagai antipiretik dan juga dehaf sebagai suplemen serta dilakukan pantau hematokrit 6 jam berikutnya.

\section{KESIMPULAN}

Pada DBD terjadi perembesan plasma yang ditandai dengan hemokonsentrasi (peningkatan hematokrit) atau penumpukan cairan di rongga tubuh. Pemeriksaan darah rutin dilakukan dilakukan untuk menepis pasien tersangka demam dengue adalah melalui pemeriksaan kadar hemoglobin, hematokrit, trombosit, dan hapusan darah tepi untuk melihat adanya limfositosis relative disertai gambar limfosit plasma biru. Diagnosis pasti dapat ditegakkan dari hasil isolasi virus dengue (cell culture) ataupun deteksi antigen virus RNA dengu dengan teknik RT-PCR (Reverse Transcriptase Polymerase Chain Reaction), namun karena teknik yang lebih rumit, saat ini tes serologis yang mendeteksi adanya antibody spesifik terhadap dengue berupa antibody total, IgM maupun IgG lebih banyak.Penatalaksanaan pada DBD prinsip utamanya adalah terapi suportif. Dengan terapi suportif yang adekuat, angka kematian dapat diturunkan hingga kurang dari $1 \%$. Pemeliharaan volume cairan sirkulasi merupakan tindakan yang paling penting dalam penanganan kasus DBD. Asupan cairan pasien harus tetap dijaga, terutama cairan oral. Jika asupan cairan oral pasien tidak mampu dipertahankan, maka dibutuhkan suplemen cairan melalui intravena untuk mencegah dehidrasi dan hemokonsentrasi secara bermakna.

\section{DAFTAR PUSTAKA}

[1] Suhendro. Demam Berdarah Dengue : Sudoyo AW, Setiyohadi B, dkk. Buku Ajar Ilmu Penyakit Dalam. Jilid III. Edisi IV. Jakarta : Ilmu 
Penyakit Dalam FKUI. 2007

[2] WHO. 2011. Conprehensive Guidelines for Prevention and Control of Dengue and Dengue Haemorrhagic Fever, India: WHO

[3] WHO. Pencegahan dan penanggulangan Penyakit Demam Dengue dan Demam Berdarah Dengue. Jakarta : WHO \& Departemen Kesehatan RI : 2003

[4] Kurane I. Dangue Hemmoragic Fever with Special Emphasis on Immunopathogenesis. Comparative Immunology, Microbiology \& Infectious Disease. 2007 : Vol 30

[5] WHO. Dengue: Guidlines for Diagnosis, Treatment, Prevention and Control. New Edition. Geneva: World Health Organization; 2009 WHO. Dengue: Guidlines for Diagnosis,
Treatment, Prevention and Control. New Edition. Geneva: World Health Organization; 2009

[6] Josi V, Sharma R. Impact of Verticallytransmitted Dengue Virus on Viability of Eggs of Virus-Inoculated Aedes aegypti. Dengue Bulletin. 2001; Vol 25:103-6.

[7] Tambyah PA, Koay ESC, Poon MLM, Lin RVTP, Ong BKC. Dengue Hemorrhagic Fever Transmitted by Blood Transfusion. The England Journal of Medicine. 2008; Vol. 359: p. 1526-7.

[8] Soegijanto S. Patogenesa dan Perubahan Patofisiologi Infeksi Virus Dengue.

www.pediatrikcom/buletin/200602208m a2gi-buletindoc; Available from: www.pediatrikcom/ buletin/200602208ma2gi-buletindoc. 